\title{
Applications GIS for earthquake threat mapping in Sabah
}

\author{
Rasyidah Raduan $^{1}{ }^{*}$, Mohd Effendi Daud ${ }^{1}$, and Masiri Kaamin ${ }^{2}$ \\ ${ }^{1}$ Faculty of Civil and Environmental Engineering, Universiti Tun Hussein Onn Malaysia, 86400 Parit \\ Raja, Batu Pahat Johor, Malaysia \\ ${ }^{2}$ Centre for Diploma Studies, Universiti Tun Hussein Onn Malaysia, 86400 Parit Raja, Batu Pahat \\ Johor, Malaysia
}

\begin{abstract}
Disaster incidents will disrupt the daily life and cause suffering to the victims of incident. The earthquake is one of the series unpredictable incident. This incident causes the concerns of academicians, engineers, planners, decision-makers and governments to prevent and manage the disaster. The disaster threat index is analyzed with using GIS software. The data that analyzed will divide into three levels which are a lower, moderate and extreme threat. The results of the analysis on the earthquake threats in Sabah revealed that $99.9 \%$ was in the area of earthquake threats with a total area is 7382144 ha while areas with no earthquake threats was $0.1 \%$ with an area is 17206 ha. From the result also, known that the high seismic hazard index is Lahad Datu with an area of 463540 ha while the lower earthquake threat index is Tambunan with an area of 588 ha. With this result, it will indirectly facilitate various parties to prepare and plan strategies to reduce the losses and damage from the earthquake disaster. Besides that, with the result also will facilitate the responsible agency to prepare an early safety plan to reduce the loss of life and property damage.
\end{abstract}

\section{Introduction}

A disaster is an occurrence disrupting the normal conditions of existence and causing a level of suffering that exceeds the capacity of adjustment to the affected community [1]. Earthquakes can destroy human infrastructure and habitat, killing and impacting large populations, especially in urban areas [2]. Malaysia has been categorized as belonging to the low seismicity group. Consequently, earthquake resistant design has not been given much emphasis until a decade ago when the Malaysian lawmakers (or Members of Parliament) were briefed by the Meteorological Department (MMD), in 2002, on the distant shock waves of the 2001 Gujarat earthquake, which travelled $600 \mathrm{~km}$ from its epicenter to rock and cause devastations to many cities in India [3].

Earthquakes do not usually occur as a single event, as mostly assumed in seismic design but as a series of shocks. Strong earthquakes have more and larger aftershocks, as well as foreshocks and the sequences can last for years or even longer. Aftershocks are usually unpredictable and can be of large magnitude, which could collapse buildings damaged from the main shock. Repetition of medium-strength earthquake ground motions after intervals of time characterize as repeated earthquakes. The interval of time can be short or long, 
taking several minutes, hours, days, or even years, but not more than the structure lifetime (i.e., 50 years) [4].

In line with the regional economic growth, many metropolises have developed rapidly in Southeast Asia in the past thirty years. Typically, seismic designs have yet to be considered in the low seismicity regions of Southeast Asia, as the regions have never experienced any earthquake disaster in their modern histories. Singapore and Kuala Lumpur, Malaysia, are two classic examples of the area with low seismic hazard, but with high consequence. Although, the active seismic sources that may affect the two cities are located more than $300 \mathrm{~km}$ away, they have generated numerous earthquakes that shook high-rise buildings in the two cities to a perceptible level and the number of felt events is increasing in the recent years due to rapid constructions of high rise structures in these metropolises. Although earthquakes have never caused any structural damage in Singapore and Kuala Lumpur, the consequences of even a moderate level of ground motion may be enormous because the high concentration of population and commercial activities taking place in structures that have not been designed for seismic loads [5].

Disaster is an event or series events that threatens and disturbs the lives of people caused by factors of nature and not a nature. The effects of this disaster are death, environmental damage, property loss and psychological impact to the victim. The catastrophe earthquake is a disaster event that unpredictable but the impact can be mitigated by disaster reduction. The surrounding area near the source of the earthquake is a vulnerable area. Therefore, measures or strategies to mitigate the loss and damage caused by the disaster should be do [6]. Typically, earthquakes will not happen once although most people consider it due to seismic design but it is actually one of the series surprises. Strong earthquakes will have more and bigger major earthquakes or vibrations (foreshocks) and the sequence of events can last for years or longer. Aftershocks earthquakes are usually unpredictable and can occur with great magnitude that can cause buildings to collapse and damaged due to major shocks [4].

An earthquake can also cause great damage to life, structure and public facilities in areas already prepared or less prepared even when they are aware. Therefore, it is important to make plans that can set priorities for prevention, reduction, and compensation for affected areas. Government and public awareness should play an important role in reducing human-financial losses as a result of earthquakes. In this case, the planner needs to know what was supposed to be done first to reduce the danger [7].Typically geological local hazard measurements which is earthquakes causing the peak ground acceleration (PGA) or the maximum acceleration experienced by physical bodies such as the movement of a building on the ground during the earthquake. PGA is considered a good hazard measure for low-rise buildings up to about seven floors [8]. This PGA measurement method is not the same as the freed energy which give an idea how the earth can shake [9].

Knowledge of earthquakes is a relatively new field in Malaysia. This is because the position of Malaysia which has been deemed stable by the community has led to a lack of research. However unnoticed by the community, in fact the study has begun to be carried out. The earthquake engineering education is very much needed in the effort to raise awareness among the various communities and to minimize the risk [10].

\section{Map of earthquake threats}

The threat map is representation a territory or location that have a particular threat or danger. For example, a landslide map and a map of flood-prone areas. This threat map is designed to provide location information according to the threat level either low, moderate or extreme. There are three main inputs to calculate earthquake threat maps which are [11]:

i. Rate of earthquake events in related areas. 
ii. Distribution of magnitude quake between small and large events.

iii. The level of ground shaking at the distance and magnitude of the earthquake.

So, the earthquake hazard assessment is one of the efforts to investigate the potential of earthquake threat in certain areas. This study includes the history of earthquakes, the area of earthquake threat, the extent of earthquake threat, the potential of future earthquakes and the vulnerability in society [12].

The disaster threat index is compiled based on two main components which are first is possibility occurrence of a threat and frequency while a second component is the major impact that has been recorded in the disaster. Therefore, it can be said as an index compiled based on data and history records of events that have occurred in a particular area. In the preparation of threat maps, the key components are mapped using GIS software. New mapping can be implemented after all indicator data on each component is obtained from a predetermined data source. Then the data were divided into 3 levels of threats namely low, moderate and extreme [13]. Table 1 shows the components and indicators to calculate the disaster threat index.

Table 1. Components and indicators of the earthquake threat index [14]

\begin{tabular}{|c|c|c|c|c|c|}
\hline \multirow{2}{*}{\multicolumn{2}{|c|}{ Components/ Indicators }} & \multicolumn{3}{|c|}{ Index level } & \multirow{2}{*}{$\begin{array}{c}\text { Total } \\
\text { weighted }\end{array}$} \\
\hline & & Low & Moderate & Extreme & \\
\hline i) & $\begin{array}{l}\text { Earthquake Threat Map (Distance from } \\
\text { active fault, MMI } 10 \text { years, frequency } \\
\text { rupture, geomorphology and geology) } \\
\text { Earthquake zone map (confirmed with } \\
\text { incident data) }\end{array}$ & $\begin{array}{c}\text { Low } \\
\text { (pga } \\
\text { value } \\
<0.250 \\
1)\end{array}$ & $\begin{array}{c}\text { Moderate } \\
\text { (pga value } \\
0.2501- \\
0.70)\end{array}$ & $\begin{array}{l}\text { Extreme } \\
\quad(\mathrm{pga} \\
\text { value> } \\
0.7)\end{array}$ & $100 \%$ \\
\hline
\end{tabular}

\section{Earthquake Threat Stage}

Several types of hazard maps have been issued by ministries and relevant agencies in determining the level of disaster threats. Among the maps of disaster threats that have been issued by the ministry are earthquakes, landslides, volcanoes, floods and droughts. Therefore, Syamsul Maarif, the chairman of the national disaster management agency, suggested that researchers use the threat maps as a guide for uniformity of data and analysis [13]. For field value classification of earthquake threat, it can be use the values at table 2 . Land degradation occurring at every earthquake can be analyzed through peak ground acceleration (PGA) values at an area or place. Large or small the peak ground acceleration value is a factor that indicates the level of the earthquake threat [15].

Table 2. The value of threatened classification on earthquake disaster [14]

\begin{tabular}{|c|c|c|c|c|}
\hline PGA value & Level & Value & Weighted (\%) & Score \\
\hline$<0.26$ & Low & 1 & \multirow{3}{*}{100} & 0.333333 \\
\hline $0.26-0.70$ & Moderate & 2 & & 0.666667 \\
\hline$>0.70$ & Extreme & 3 & & 1.000000 \\
\hline
\end{tabular}

\section{Methodology}

A lot of data is needed to manage disaster especially in the process of making disaster risk mapping. Most of this data contains spatial components that show the need for analysis and visualization. Geographic Information System (GIS) is a system for recording, storing, 
analyzing and managing spatial data that refers to the earth and can be used in making plans and decisions. GIS can collect, store, manipulate and display referenced geographic data, link data to points, lines and areas within a map or in a table. Therefore, GIS can use the geographic data generated during the disaster and provide information based on the location of the incident that can be used during the decision-making process [16]. Figure 1 shows the flow chart of this research. In this research, components and indicators need to be identified before the data collection. Furthermore, once the data is collected, the threat index classification is determined. During the threat classification process, a parameter of index level, scores and weighted are required. Finally, the threat map is generated based on the classification that has been created.

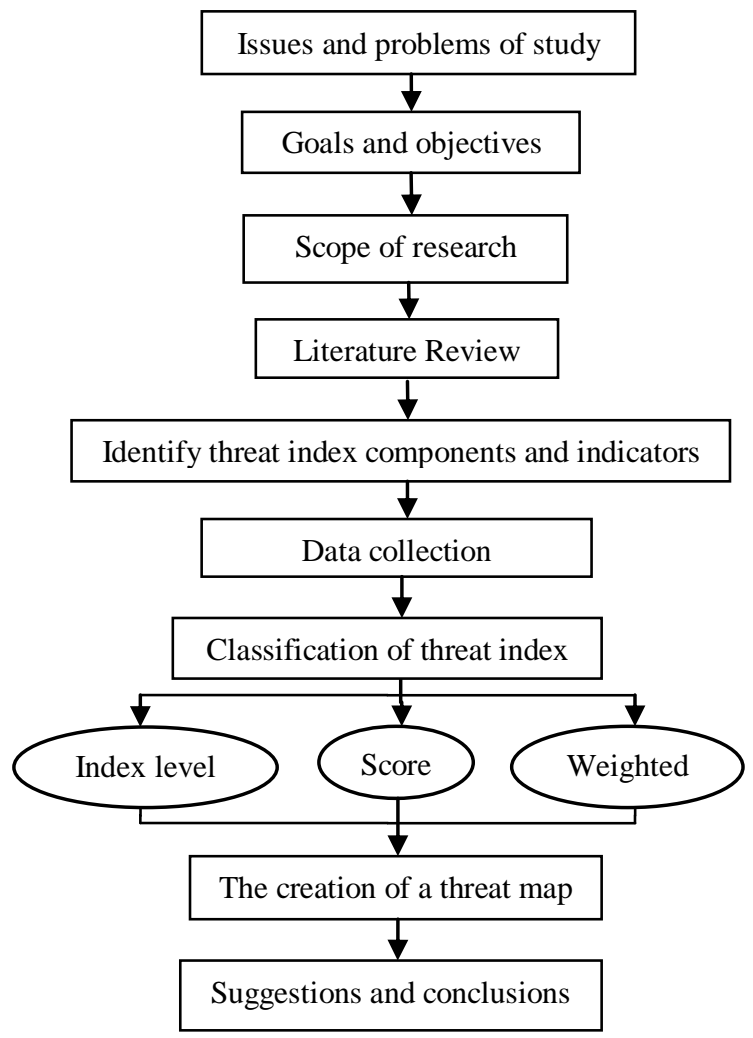

Fig. 1. Flow charts

\subsection{Determination of threat index}

In determining the earthquake threat index, supporting data is needed during analysis to produce an earthquake threat map in Sabah. The data needed in mapping earthquake threat is digital geospatial data. In addition, geological data and fault lines in sabah are also needed in determining the index of earthquake threats. Next, to create a threat map, overlay and analysis using field calculator and raster calculator needs to be done which applies analysis calculations in accordance with the determination for classification of the threats to earthquake disaster. As a result of processing using the raster calculator, maps describing information on extreme, moderate and low areas for earthquake threats in Sabah can be 
known.

For earthquake threat mapping is using GIS software because GIS can help improve organizational integration, allows users to view, understand, question, interpret, and visualize data in many ways and express it with relationships, patterns, and trends in the form of maps, globes, reports, and charts. Besides that, GIS also can provide questions, answers and problem solving by looking at data quickly and easily understood. Additionally it can integrate every information system framework and provide more job opportunitie [17].

\section{Data analysis and mapping of earthquake threat maps}

The components required during the process of mapping earthquake threats are described in Table 1. During the process of analyzing data using ArcMap, all data obtained will be equated with units in meters using projected coordinate system WGS 1984 World Mercator. Furthermore, the classification of threats based on low, moderate and extreme classification values is performed for each component accordance with the scores that have been made using the tools in ArcGIS software which is field calculator. The classification is divided into three classes according to the scores obtained which are classification for low threat with score of 0.3333 , classification for moderate threat with score of 0.6667 and for extreme threat with score of 1 . So, table 3 show the result of threat index earthquake in Sabah.

Table 3. Threat index earthquake in Sabah

\begin{tabular}{|c|c|c|c|c|}
\hline \multirow{2}{*}{ District } & \multicolumn{2}{|c|}{ Threat Index (Ha) } & \multirow{2}{*}{ Threat area (Ha) } & \multirow{2}{*}{$\%$} \\
\cline { 2 - 3 } & Low & Moderate & 34496 & 0.5 \\
\hline Kota Kinabalu & 34496 & 0 & 46844 & 0.6 \\
\hline Penampang & 46844 & 0 & 45276 & 0.6 \\
\hline Kuala Penyu & 45276 & 0 & 107016 & 1.4 \\
\hline Semporna & 40376 & 66640 & 113288 & 1.5 \\
\hline Kunak & 62328 & 50960 & 117208 & 1.6 \\
\hline Tuaran & 117208 & 0 & 127008 & 1.7 \\
\hline Papar & 127008 & 0 & 123284 & 1.7 \\
\hline Kudat & 123284 & 0 & 134064 & 1.8 \\
\hline Tambunan & 133476 & 588 & 137200 & 1.9 \\
\hline Kota Belud & 137200 & 0 & 150332 & 2 \\
\hline Pitas & 150332 & 0 & 173656 & 2.3 \\
\hline Beaufort & 173656 & 0 & 176008 & 2.4 \\
\hline Kota Marudu & 176008 & 0 & 219520 & 3 \\
\hline Sandakan & 219520 & 0 & 242060 & 3.3 \\
\hline Tenom & 242060 & 0 & 271656 & 3.7 \\
\hline Sipitang & 271656 & 0 & 295960 & 4 \\
\hline Ranau & 276752 & 19208 & 361816 & 4.9 \\
\hline Keningau & 361816 & 0 & 592704 & 8 \\
\hline Pensiangan & 592704 & 0 & 611128 & 8.3 \\
\hline Tawau & 609952 & 1176 & 707560 & 9.6 \\
\hline Kinabatangan & 635628 & 71932 & 744800 & 10.1 \\
\hline Lahad Datu & 281260 & 463540 & 857696 & 11.6 \\
\hline Labuk Dan Sugut & 857696 & 0 & 991564 & 13.4 \\
\hline Tongod & 991564 & 0 & 7382144 & 99.9 \\
\hline Total & 6708100 & 674044 & & \\
\hline & & & & \\
\hline
\end{tabular}


Based on the results of the analysis and data collection, then the earthquake threat stage using ArcMap software can be created. From the ArcMap software, it can be seen that areas of moderate risk threats are colored yellow and low-risk threats are colored green (fig. 2).

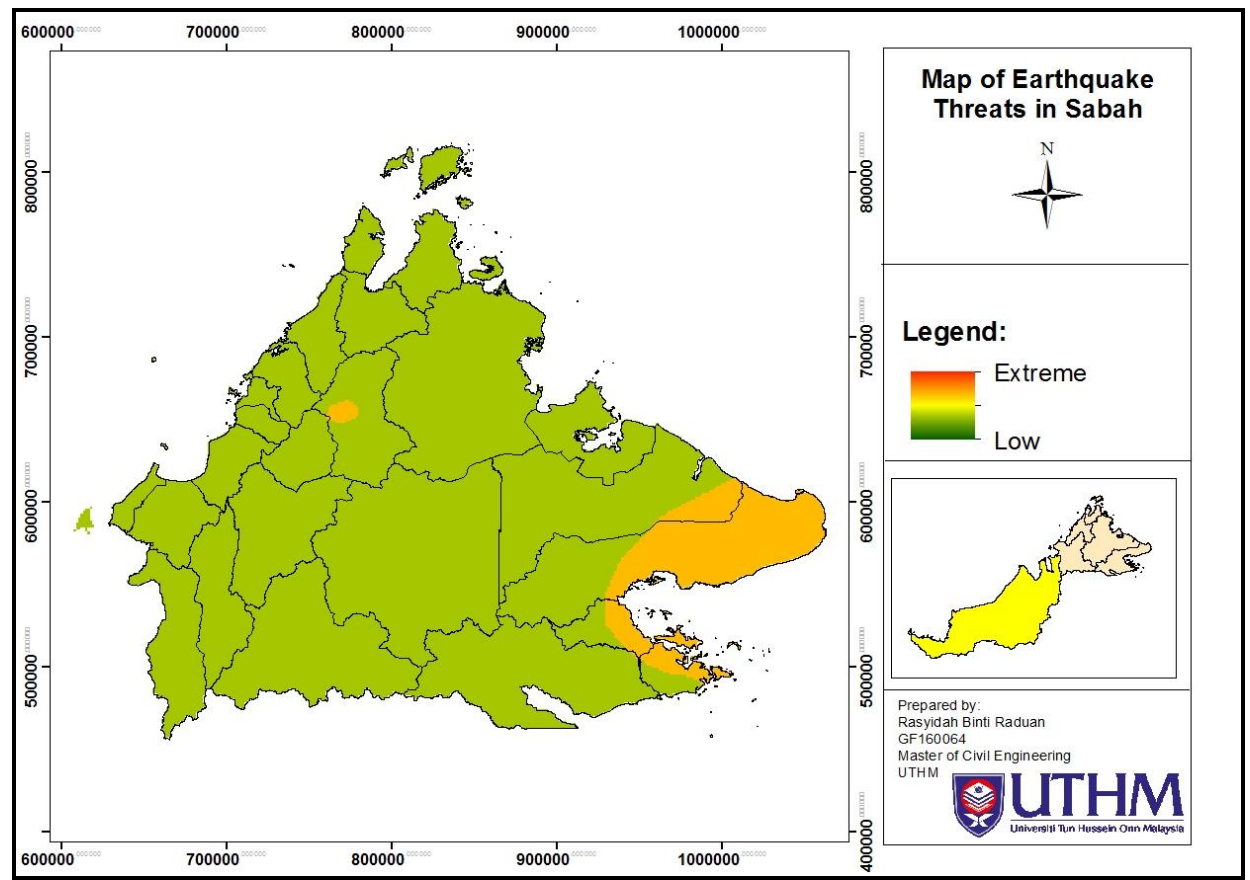

Fig. 2. Map of earthquake threats in Sabah

In overall, as a result of the analysis on the level of earthquake threats in Sabah, it was found that $99.9 \%$ was an area within the threat of earthquake with a total area 7382144 Ha while the area with no earthquake threat was $0.1 \%$ with a total area $17206 \mathrm{Ha}$. Table 3 shows the index of earthquake threats based on districts in Sabah. From the table it was found that no district was in the area of extreme threat index but 7 districts were within the medium threat area index with a total area $674044 \mathrm{Ha}$. The high area of the moderate earthquake threat index is the Lahad Datu disctrict with a total area $463540 \mathrm{Ha}$ while the low area of the moderate earthquake threat index is Tambunan district with a total area 588 Ha. The district of Lahad Datu is a high level of moderate threat area because Lahad Datu's Fault Lines and Tabin Fault Lines lie within the Lahad Datu district. If seen in the district of Tambunan, the level of threat is relatively low compared to Tawau, Semporna, Kunak, Kinabatangan, Ranau and Lahad Datu district because the fault lines are located outside the Tambunan district. The fault line near the Tambunan district is Lobou-Lobou Fault Line, Lugas Fault Line, Keningau Fault Line and Kinayan Fault Line. Although the total area of Tongod threats with Labuk and Sugut is high but the area is not within a moderate threat index but the area is in a low threat index. This suggests that the total area of high threats on an area is not a determinant that the area is in extreme threat. Therefore, to know the threat level of an area its should be seen on the threat indexes either low, moderate or extreme. 


\section{Discussion and conclusion}

The earthquake threat mapping is important to various agencies as a preparation and precautionary measures in case of aftershocks. Therefore, the results of this research are expected to provide a few useful contributions to all agencies. This research can also be used as a guide to responsible parties in planning security plans and measures to create awareness among locals on factors, causes, signs, etc. related to earthquakes to ensure the welfare of the population is assured. This is because, in the earthquake threat map the area affected by the earthquake along with digital geospatial data can be known.

\section{References}

1. Anton Lundkvist, Development of a Web GI System for Disaster Management. (2017)

2. John. Radke, Tom Cova, Michael F. Sheridan, Austin Troy, Lan Mu, and Russ Johnson, Challenges for GIS in Emergency Preparedness and Response. (2000)

3. Sherliza Zaini Sooria, Sumio Sawada, and Hiroyuki Goto, "Proposal for Seismic Resistant Design in Malaysia : Assessment of Possible Ground Motions in Peninsular Malaysia," Annu. Disaster Prev. Res. Inst. Kyoto Univ., vol. 55, pp. 81-94, (2012)

4. Ade Faisal, Taksiah A. Majid, and George D. Hatzigeorgiou, "Investigation of Story Ductility Demands of Inelastic Concrete Frames Subjected to Repeated Earthquakes," Soil Dyn. Earthq. Eng., vol. 44, pp. 42-53, (2013)

5. Kusnowidjaja Megawati, Tso-Chien Pan, and Kazuki Koketsu, "Response spectral attenuation relationships for Sumatran-subduction earthquakes and the seismic hazard implications to Singapore and Kuala Lumpur," Soil Dyn. Earthq. Eng., vol. 25, no. 1, pp. 11-25, (2005)

6. [Niko Irjaya Desmonda and Adjie Pamungkas, "Penentuan Zona Kerentanan Bencana Gempa Bumi Tektonik di Kabupaten Malang Wilayah Selatan,” J. Tek. Pomits, vol. 3, no. 2, pp. 107-112, (2014)

7. Noushin Naraghi Araghi, "Probabilistic Seismic Hazard Analysis In Tehran And Adjacent Area," (2015)

8. Jérémie Gignoux Gignoux and Marta Menéndez, "Benefit in the wake of disaster: Long-run effects of earthquakes on welfare in rural Indonesia," J. Dev. Econ., vol. 118, pp. 26-44, (2016)

9. Bharwani Hemlata Motiram, Earthquake Risk Assessment, Loss Estimation and Vulnerability Mapping for Dehradun City, India. (2014)

10. Mohd Zamri Ramli and Zaida Torman, Pembelajaran melalui pertandingan. (2011)

11. David Burbidge, "Estimating of the Rate of Deformation of Australia for the National Earthquake Hazard Map," (2009)

12. Sulastri Shahzad and Bambang Sunardi, "Indeks Bahaya Gempabumi; Studi Kasus Desa Pleret, Kabupaten Bantul," J. Ris. Geofis. Indones., vol. 1, no. 1, pp. 1-6, (2017)

13. Mahdi Anzala, Eldina Fatimah and Nazli Ismail, "Kajian pemetaan kawasan risiko gempa bumi di Kabupaten Aceh Tengah," J. Ilmu Kebencanaan, vol. 2, no. 1, pp. 19-27, (2015)

14. Syamsul Maarif, Pedoman Umum Pengkajian Risiko Bencana. (2012)

15. Ni Made Rysnawati, I Ketut Sukarasa and Ida Bagus Alit Paramarta, "Analisa Tingkat Bahaya Dan Kerentanan Bencana Gempa Bumi Di Wilayah Nusa Tenggara Timur (NTT)," Bul. Fis., vol. 18, no. 1, pp. 32-37, (2017) 
16. Mifan Careem, David Bitner and Ravindra de Silva, "Gis Integration in The Sahana Disaster Management System," Proc. ISCRAM, pp. 211-218, (2007)

17. Ang Kean Hua, "Sistem Informasi Geografi (GIS): Pengenalan Kepada Perspektif Komputer,” Malaysian J. Soc. Sp., vol. 11, no. 1, pp. 24-31, (2015) 